\title{
EARLY EVALUATION OF RECLAMATION PROGRESS ON NATURAL GAS WELLPADS IN WYOMING ${ }^{1}$
}

\author{
P.D. Stahl ${ }^{2}$
}

\begin{abstract}
Successful reclamation of established natural gas production well pads is required before natural gas producers can expand operations in Wyoming. Early evaluation of reclamation progress on interim reclaimed well pads has been proposed as a policy to increase production in natural gas fields. The objective of this paper is to present proposed criteria to be used in this evaluation. Early reclamation appraisal would not be conducted until at least two full growing seasons after seeding, or, if irrigation is used, at least two full growing seasons after supplemental irrigation is terminated. Evaluation will be based upon examination of reestablished vegetation and reconstructed soil. Characteristics of vegetation to be required include domination of the new plant community by seeded perennials, full expression of the approved seed mix and limited presence of noxious weeds. Reclaimed soil characteristics to be examined include $\mathrm{pH}$, electrical conductivity (EC), organic carbon content, aggregate stability, texture and indicators of erosion. Values of these properties of soils on the reclaimed sites are required to be within certain comparable ranges to soil originally present on the site and to nearby undisturbed soil in reference areas.
\end{abstract}

Additional Key Words: revegetation, soil reconstruction, interim reclamation, bond rollover

${ }^{1}$ Paper was presented at the 2010 National Meeting of the American Society of Mining and Reclamation, Pittsburgh, PA Bridging Reclamation, Science and the Community June 5 - 11, 2010. R.I. Barnhisel (Ed.) Published by ASMR, 3134 Montavesta Rd., Lexington, KY 40502.

${ }^{2}$ Peter D. Stahl, Director, Wyoming Reclamation and Restoration Center and Professor of Soil Ecology, Department of Renewable Resources, College of Agriculture, University of Wyoming, Laramie, WY 82071.

Proceedings America Society of Mining and Reclamation, 2010 pp 1179-1183 DOI: $10.21000 / \mathrm{JASMR} 10011179$ http://dx.doi.org/10.21000JASMR10011179 


\section{Introduction}

Wyoming is currently the nation's leading on-shore producer of natural gas and is undergoing a large boom in gas production. The Wyoming Oil and Gas Regulations developed by the Wyoming Oil and Gas Conservation Commission (WOGCC), require a permit and bond be posted before drilling any oil or gas well in the state. Bonds can be posted for individual wells (individual bond) or a blanket bond can be posted for all wells in a given permit area. Individual bonds for wells less than 608 meters deep $(2,000 \mathrm{ft})$ are $\$ 10,000$ for each well and $\$ 20,000$ for wells greater than 608 meters $(2,000 \mathrm{ft})$ in depth. Blanket bonds for multiple wells in a permit area cost $\$ 75,000$ (WOGCC, 2008). Bonds are generally held by WOGCC until the well is out of production, permanently plugged and final site reclamation completed (Andersen and Coupal, 2009).

In Wyoming, the Bureau of Land Management (BLM), which manages and determines policy on millions of hectares of federal rangeland in the state has established a cap on the amount of land allowed to be disturbed by oil and gas drilling in specific permit areas. For example, in one large, ecologically important area currently under intense development, the Atlantic Rim, BLM has limited disturbance by gas wells under a blanket permit to 3078 hectares (7,600 acres), with no more than 2.64 hectares (6.5 acres) disturbed by any individual well. No limit has been set on the total land area disturbed by drilling by all producers working in the Atlantic Rim, only on blanket permits held by individual producers (BLM, 2009).

These regulations have created a major problem for oil and gas operators wanting to produce as much gas as possible in a specific permit area. The life of a single well may be 20-25 years or more and bond is held until well production has ceased, been capped and reclaimed. Once an operator meets the disturbance limit of their permit, they must wait long periods of time until wells go out of production and are reclaimed before new wells can be drilled.

A new policy has been proposed to alleviate this problem by giving producers credit for the interim reclamation they conduct while the wells are in production (BLM, 2009). Interim reclamation is implemented immediately after the well is installed to stabilize and revegetate the well site so it is in an acceptable reclaimed condition while in production. The short term goal (of interim reclamation) is to immediately stabilize disturbed areas and provide conditions necessary to achieve the long-term sustainable goal. The long term goal is to facilitate eventual 
ecosystem reconstruction to maintain a safe and stable landscape and meet the desired objectives of the land use plan (BLM, 2009). When the well ceases production, the producer must salvage the topsoil again and then remove all of the hardware associated with the well. When all the production equipment is removed from the site, final reclamation is conducted. The proposed new policy would give producers credit for reclamation of the site after successful interim reclamation is completed rather than after final reclamation is accomplished. This would effectively decrease the time producers must wait before being given credit for reducing the amount of disturbed land in their permit area through interim reclamation of previously installed wells. Instead of a period 20 years or more to decommission a well and complete a second round of reclamation (final reclamation) before credit is given, rollover credit for interim reclamation could be obtained as little as two years after the well is installed.

The objective of this paper is to describe the requirements for participation in the rollover program and the criteria by which successful interim reclamation of oil and gas well pads would be evaluated under this new policy in Wyoming.

\section{Well Pad Installation and Reclamation}

The process of installing a well pad, conducting interim reclamation, production, decommissioning and final reclamation can last 20 years or more depending on the productivity of the well. After necessary permits for well drilling are obtained, bond posted and acceptable drilling and reclamation plans are formulated, earthwork can begin. The first work on the site is removal of topsoil for salvage and later reuse. The well is then drilled, outfitted and completed. After the well is installed, interim reclamation is conducted including topsoil replacement and revegetation. If the new policy is implemented, success of this interim reclamation could be evaluated two growing seasons after seeding if no irrigation was used to revegetate the well pad. If the site was irrigated to facilitate revegetation, reclamation cannot be evaluated until two growing seasons after irrigation was removed. After interim reclamation is accomplished, the well may continue production for 20 years or more. When production has ceased and the well is ready for decommission, the topsoil on the site is removed once again and stockpiled. The well and all associated hardware are then removed from the site. The site is then recontoured and the topsoil reapplied followed by reseeding. Under current regulations, producers are not given 
rollover credit for reclamation until this final reclamation has been considered successful and approved.

\section{Requirements of the Program}

The Interim (Rollover) Reclamation Program will require a Phase 1 development of a comprehensive Reclamation Plan. This planning must include a pre-disturbance inventory of the proposed well sites and the adjacent areas which addresses 1) landscape features and climate, 2) soils inventory including basic characterization of the A and B horizons, 3) vegetation inventory including photographs of pre-disturbance vegetation and selection of a reference area for future comparative use, 4) invasive plant management plan for use during construction and reclamation.

The Reclamation Plan must also address 1) site preparation, surface stability and soil management, 2) seeding methods, 3) soil amendments, 4) seed mixes, 5) irrigation practices, 6) best management practices (BMPs), including invasive species control and 7) monitoring and reporting protocols.

Phase 2 of the Interim (Rollover) Reclamation Program involves assessment of Interim Reclamation.

\section{Criteria for Evaluation of Interim Reclamation}

- Monitoring of reclaimed well sites should begin the first growing season after seeding. Evaluation of reclamation progress and success is possible after a minimum of two full growing seasons after seeding. If irrigation is used on the site, then evaluation cannot be done until two full growing seasons after irrigation is terminated to demonstrate the plant community can survive after removal of irrigation.

- Total ground cover of the reestablished plant community should be at least $70 \%$ of reference area cover. The entire $70 \%$ must be desirable perennial species as specified in the reclamation plan.

- Full expression of the approved seed mix as determined by examination of individual species cover. Species included in the seed mix should be represented in the reestablished vegetation based on their relative percentage of the seed mix. 
- No noxious weeds will be allowed. Invasive species cover in reestablished vegetation can be no greater than that in reference area. Undesirable plants as defined in the Reclamation Plan must be controlled on the disturbed area.

If reclamation progress (or site recovery) is not positive, i.e., reestablished plant community characteristics are not improving, within 3 full growing seasons without irrigation or two full growing seasons after irrigation, intervention or reseeding should be considered.

\section{Summary}

If this Interim (Rollover) Reclamation Program were implemented, natural gas producers would be eligible for early reclamation rollover credit if they develop a site specific comprehensive reclamation plan including pre-disturbance inventories of well pad sites. This program would also require producers to demonstrate successful reclamation progress within 3 growing seasons after seeding based on evaluation of reestablished plant community characteristics of reclaimed well pads.

\section{$\underline{\text { Literature Cited }}$}

Andersen, M. and R. Coupal. 2009. Economic issues and policies affecting reclamation in Wyoming's oil and gas industry. Proceedings America Society of Mining and Reclamation, 2009 pp 1-17, http://dx.doi.org/10.21000/JASMR09010001,

BLM. 2007. Surface Operating Standards and Guidelines for Oil and Gas Exploration and Development. The Gold Book. Fourth Edition. BLM National Science and Technology Center, Denver, CO.

BLM. 2009. Wyoming State Office. Instruction Memorandum No. WY-2009-022. March 31, 2009

WOGCC. 2008. Rules and Statutes, revised Chapter 3, Section 4. Available on line http://wogcc.state.wy.us/rules-statutes.cfm?Skip=' ${ }^{\prime}$ ' 